\title{
Effects of Somatostatin on Muscarinic Acetylcholine Receptor Binding in the Rat Hippocampus
}

\author{
Rie MIYOSHI, Shozo KITO, Kumiko MIZUNO \\ and Hiroaki MATSUBAYASHI \\ Third Department of Internal Medicine. Hiroshima University School of Medicine, \\ 1-2-3 Kasumi, Minami-ku. Hiroshima 734, Japan \\ Accepted October 31, 1985
}

\begin{abstract}
The authors noticed effects of somatostatin on muscarinic acetylcholine receptors (mAchR) in the rat hippocampus from binding experiments. Saturation experiments of ${ }^{3} \mathrm{H}$-oxotremorine- $\mathrm{M}$-acetate $\left({ }^{3} \mathrm{H}\right.$-oxo-M) buffered with KrebsHenseleit solution revealed that there were two binding sites with very high and low affinities whose $K_{d}$ values were $1.2 \mathrm{nM}$ and $445.8 \mathrm{nM}$, respectively. Adding somatostatin in this incubation medium caused an increase in the $K_{d}$ value of the high affinity binding site with no change in the $B_{\max }$ value. As for the low affinity binding site, $K_{d}$ and $B_{\max }$ values were too large to determine the effect of somatostatin. The oxotremorine $/{ }^{3} \mathrm{H}-\mathrm{N}$-methyl-scopolamine competition experiments indicated the presence of two components of agonist binding sites. The inhibition curve after adding somatostatin fitted best to a single homogenous binding site whose $K_{i}$ value was consistent with the dissociation constant of the oxotremorine low affinity binding site. Therefore, it seems that somatostatin accelerates conformational changes of the oxotremorine high affinity binding site to the low affinity binding state. A single binding site with a $K_{d}$ value of $30.9 \mathrm{nM}$ was obtained by switching the buffer to Na-K phosphate solution. The affinity of this binding site was likewise inhibited by somatostatin. The inhibitory effect of somatostatin-28 was more marked than that of $\left[\mathrm{D}-\operatorname{trp}^{8}\right]$ somatostatin. The above-mentioned effects of somatostatin was limited to $m A c h R$ agonist binding.
\end{abstract}

Recently, the cholinergic theory of senile dementia has been advocated, whereas complex networks within the hippocampus is considered to be related to the memory mechanism. These days, much attention has been focused on coexistence of neurotransmitters chiefly from histochemical viewpoints. There have been several papers which suggest that some of the neuropeptides affect the turnover rate of acetylcholine in the hippocampus, and a possible regulatory mechanism of neuropeptides on the synaptic transmission of conventional neurotransmitters is assurned (1).

In this paper, the authors studied effects of somatostatin on cholinergic muscarinic receptors in the hippocampus using the binding technique.

\section{Materials and Methods}

Male rats of the Wistar strain, weighing $200 \mathrm{~g}$, were decapitated. After rapid removal of the hippocampus, the $P_{2}$ fraction of the tissue was prepared by the method of De Robertis et al. (2). The tissue was homogenized in 10 volumes $(\mathrm{W} / \mathrm{v})$ of ice-cold $0.32 \mathrm{M}$ sucrose, and the homogenate was centrifuged at $900 \mathrm{~g}$ for $10 \mathrm{~min}$. The supernatant was then centrifuged at $11500 \mathrm{~g}$ for $20 \mathrm{~min}$. The resulting pellet was resuspended in KrebsHenseleit buffer. Protein concentrations were determined by the method of Lowry et al. Muscarinic acetylcholine receptor (mAchR) agonist binding experiments were performed using ${ }^{3} \mathrm{H}$-oxotremorine- $\mathrm{M}$-acetate $\left({ }^{3} \mathrm{H}\right.$-oxo$\mathrm{M})$ as the radioactive ligand and $10^{-4} \mathrm{M}$ 
acetylcholine as the non-radioactive ligand. Aliquots of the tissue preparation $(0.3 \mathrm{mg}$ wet weight $/ \mathrm{ml}$ ) were incubated in KrebsHenseleit buffer $(\mathrm{pH} 7.4)$ at $30^{\circ} \mathrm{C}$ for $8 \mathrm{~min}$ with and without $1 \mu \mathrm{M}\left[\mathrm{D}\right.$-trp $\left.{ }^{8}\right]$ somatostatin. To prevent degradation of somatostatin, pepstatin, bacitracin and bovine serum albumin were added. In addition, the effect of somatostatin on oxotremorine binding was observed through oxotremorine $/{ }^{3} \mathrm{H}-\mathrm{N}$ methyl-scopolamine ( $\left.{ }^{3} \mathrm{H}-\mathrm{NMS}\right)$ competition experiments. The assay buffer was Krebs-Henseleit solution, and the tissue homogenate $(0.03 \mathrm{mg}$ wet weight $/ \mathrm{mg})$ was incubated at $30^{\circ} \mathrm{C}$ for $15 \mathrm{~min}$. Non-specific binding was determined by $1 \mu \mathrm{M}$ atropine.

Membrane bound ${ }^{3} \mathrm{H}$-ligand was trapped at the end of the incubation period by rapid vacuum filtration of the incubation mixture over Whatman glass fiber filters (GF/B). The filters were rinsed with three aliquots $(5 \mathrm{ml})$ of Krebs Henseleit solution, and trapped radioactivity was measured subsequently by liquid scintillation spectrophotometry.

Furthermore, we studied using either ${ }^{3} \mathrm{H}$ ONB or ${ }^{3} \mathrm{H}-\mathrm{NMS}$ whether such effects of somatostatin occurred in the case of antagonistic muscarinic receptor binding.

A one-site model with a Hill coefficient and a two-site model were fitted to experimental data by nonlinear least square regression using a computer program (SIMPLEX) from the program library of the Computation Center, Osaka University, Japan. The $K_{d}$ and $B_{\max }$ values of two binding sites were calculated with a program which fitted a hyperbola to the Scatchard plots and gave two asymptotes of the hyperbola. A microcomputer (NEC PC 9801) was used for these analyses. For a single binding site, the $K_{d}$ and $B_{\max }$ values were determined by least square regression analysis of Scatchard plots.

\section{Results}

Saturation curves for ${ }^{3} \mathrm{H}$-oxo- $\mathrm{M}$ are shown in Fig. 1. Scatchard analysis of saturation experiments of ${ }^{3} \mathrm{H}$-oxo- $\mathrm{M}$ binding revealed two types of binding sites, a very high affinity binding site whose $K_{d}$ and $B_{\max }$ values were $1.2 \mathrm{nM}$ and $53.6 \mathrm{fmol} / \mathrm{mg}$ protein, respectively, and a low affinity binding site with a $K_{d}$ value of $445.8 \mathrm{nM}$ and a $B_{\max }$ value of $1,337.5 \mathrm{fmol} / \mathrm{mg}$ protein. By adding $1 \mu \mathrm{M}$ [D-trp $\left.{ }^{8}\right]$ somatostatin, the $K_{d}$ value of the high affinity binding site increased to $6.7 \mathrm{nM}$ with a $B_{\max }$ value that was unchanged $(65.1$ fmol/mg protein). $K_{d}$ and $B_{\max }$ values of the low affinity binding site were too large to determine how somatostatin influenced this binding site. We confirmed that pepstatin and bacitracin did not influence the ${ }^{3} \mathrm{H}$-oxo-M binding. These values were the means in three repeated experiments.

An oxotremorine $/{ }^{3} \mathrm{H}$-NMS curve exhibits heterogenous characteristics with a Hill coefficient much less than 1 as shown in Fig. 2. These values were means in four repeated experiments. The binding data in the rat hippocampus were fitted best by a two-site model, characterized by two dissociation constants: a $K_{H}$ value of $6.6 \times 10^{-9}$ $\mathrm{M}$ and a $\mathrm{K}_{\mathrm{L}}$ value of $2.6 \times 10^{-6} \mathrm{M}$. Percentages of high and low affinity binding sites to the total binding capacity are shown in Fig. 2 . The inhibition curve after adding somatostatin in the incubation medium exhibited a Hill slope factor close to 1 , and the curve fitted best to a binding model consisting of a single homogenous binding site whose $K_{i}$ value was consistent with $\mathrm{K}_{\mathrm{L}}$.

The association rate of ${ }^{3} \mathrm{H}$-oxo- $\mathrm{M}$ binding was very rapid, reaching equilibrium in 60 seconds (Fig. 3). These values were the means of five separate determinations. The specific binding at any prior time to equilibrium ( $B$ ) is related to the one at equilibrium, $\mathrm{Be}$, by the following equation: In $\mathrm{Be} /(\mathrm{Be}-\mathrm{B})=$ $\mathrm{K}_{\mathrm{ob}} \mathrm{t}$. Plots of $\mathrm{In} \mathrm{Be} /(\mathrm{Be}-\mathrm{B})$ vs. $t$ will have a slope of $K_{o b}$. $K_{o b}$ values with and without somatostatin were $0.097 \pm 0.004 \mathrm{sec}^{-1}$ and 0.051 $\pm 0.007 \mathrm{sec}^{-1}$, respectively. The inhibitory effect of somatostatin-28 was more potent than that of $\left[D-\operatorname{trp}^{8}\right]$ somatostatin as shown in Fig. 4.

The authors performed the same experiments using $\mathrm{Na}-\mathrm{K}$ phosphate solution as buffer instead of Krebs-Henseleit solution. The obtained saturation analysis revealed one binding site of simple mass action behavior with a $K_{d}$ value of $30.9 \mathrm{nM}$ and $a$ $B_{\max }$ value of $1.345 \mathrm{fmol} / \mathrm{mg}$ protein. The affinity of this binding site was inhibited by somatostatin from $30.9 \mathrm{nM}$ to $60.1 \mathrm{nM}$ in a 

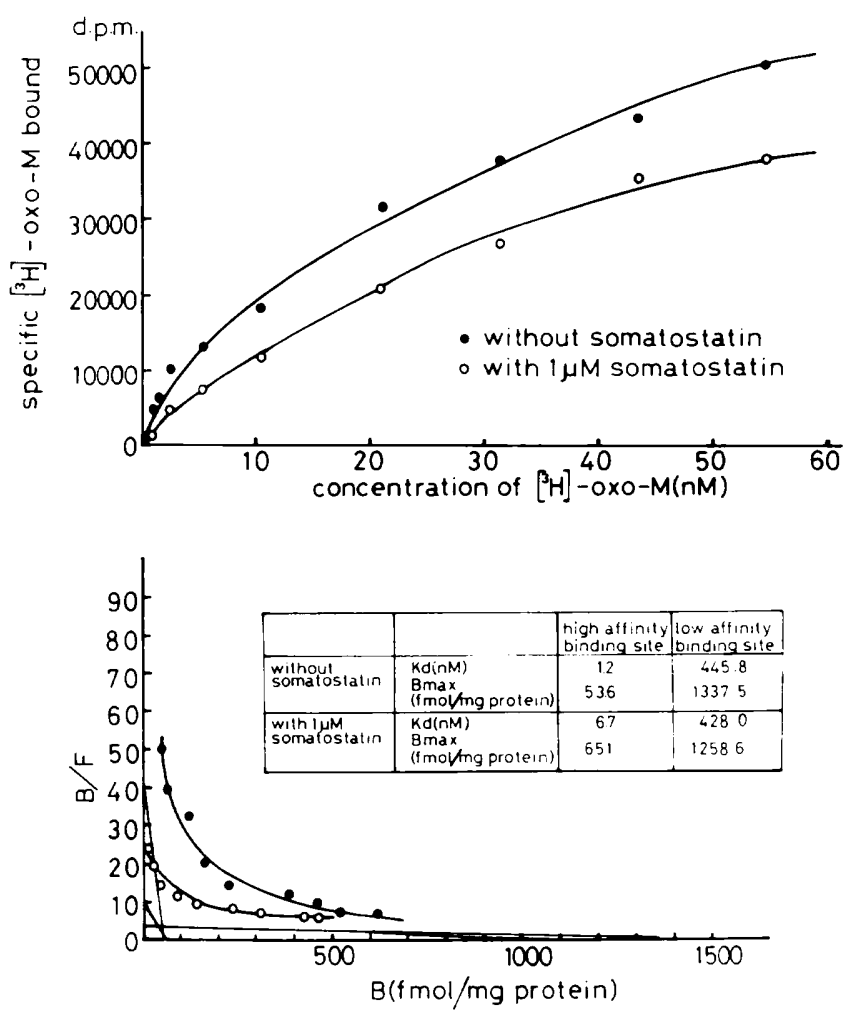

Fig. 1. Saturation isotherm and Scatchard plots of ${ }^{3} \mathrm{H}$-oxo-M binding with $(O)$ and without $(\mathbf{O}) 1 \mu \mathrm{M}$ [D-trp ${ }^{8}$ ] somatostatin. $P_{2}$ fraction of the rat hippocampus was incubated with increasing concentrations of ${ }^{3} \mathrm{H}$-oxo- $\mathrm{M}$ in Krebs-Henseleit buffer at $30^{\circ} \mathrm{C}$ for $8 \mathrm{~min}$. Acetylcholine of $10^{-4} \mathrm{M}$ was used as the non-radioactive ligand. The computer-analyzed binding data can be explained by the presence of two major populations of agonist binding sites. In the experiments using somatostatin, bovine serum albumin, pepstatin and bacitracin were added to prevent degradation of somatostatin. Somatostatin caused an increase of the $K_{d}$ value with no effect on $B_{\max }$ in the high affinity binding site.

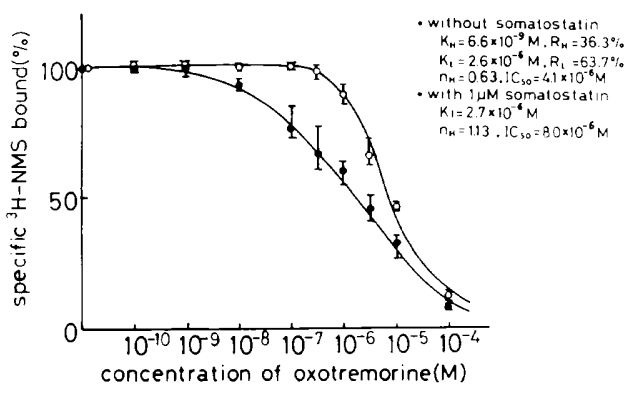

pattern identical to the case of the high affinity binding site of the preceeding experiments in which Krebs-Henseleit solution was used as buffer (Fig. 5).

The above-mentioned inhibitory effects of somatostatin on mAchR in the rat hip-
Fig. 2. Oxotremorine binding to $P_{2}$ fraction of the hippocampus measured by competition with ${ }^{3} \mathrm{H}$ NMS. The homogenate was incubated with $0.2 \mathrm{nM}$ ${ }^{3} \mathrm{H}-\mathrm{NMS}$ in Krebs Henseleit solution at $30^{\circ} \mathrm{C}$ for $15 \mathrm{~min}$. The competition curve without somatostatin (O) is very shallow, and the data fit best to a twosite model. By adding somatostatin (O), the Hill coefficient becomes about 1 , and in this case, the $\mathrm{K}_{\mathrm{i}}$ value is close to the dissociation constant of the low affinity binding site without somatostatin.

pocampus seemed to be limited to agonist binding and there was no such phenomenon on antagonist binding, since somatostatin had no effect on both ${ }^{3} \mathrm{H}-\mathrm{QNB}$ and ${ }^{3} \mathrm{H}-\mathrm{NMS}$ binding (Fig. 6). 

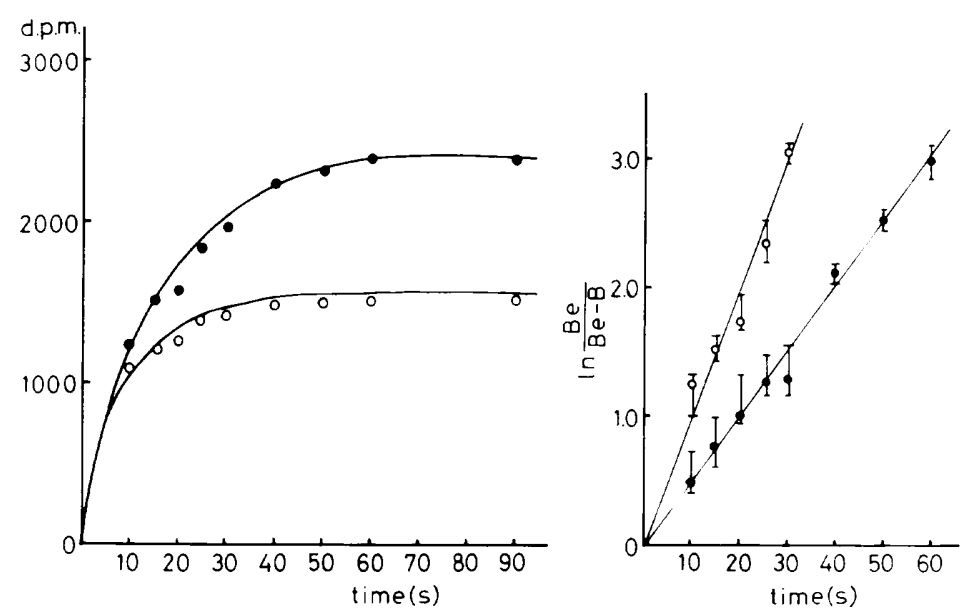

Fig. 3. Association kinetics of ${ }^{3} \mathrm{H}$-oxo-M binding. $\mathrm{P}_{2}$ fraction of the rat hippocampus was incubated with $0.4 \mathrm{nM}^{3} \mathrm{H}$-oxo-M at $0^{\circ} \mathrm{C}$ in the absence $(O)$ and presence $(\mathrm{O})$ of somatostatin. The right figure is a pseudo-first order kinetic plot of this data, where $\mathrm{B}$ represents the amount bound at time $\mathrm{t}$ and $\mathrm{Be}$ represents the amount bound at equilibrium. The slope of the linear regression line describes a $K_{0 b}$ of $0.097 \mathrm{sec}^{-1}$ and $0.051 \mathrm{sec}^{-1}$ with $(\mathrm{O})$ and without (O) somatostatin, respectively.

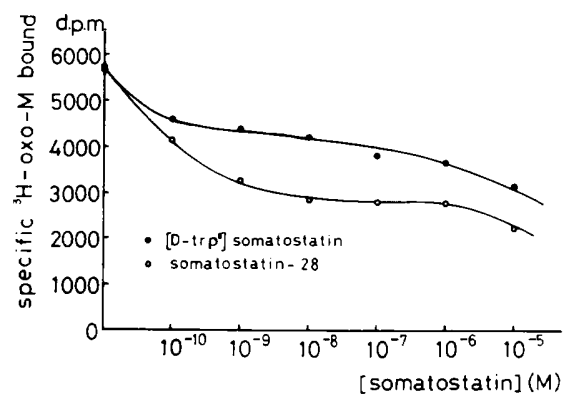

Fig. 4. The effect of various concentrations of somatostatin on ${ }^{3} \mathrm{H}$-oxo-M binding. The effect of somatostatin-28 (O) was more marked than that of [D- $\left.\operatorname{trp}^{8}\right]$ somatostatin (O).

\section{Discussion}

Recently, an increasing number of neuroscientific studies have focused on the interactions among various neurotransmitters and neuromodulators (3). There have been several papers suggesting that somatostatin interacts with conventional neurotransmitters such as GABA, serotonin (4) and acetylcholine $(5,6)$. On the other hand, decrease of somatostatin-containing neurons in the central nervous system of Alzheimer's disease has been recently documented (7), whereas the cholinergic theory of this disease in

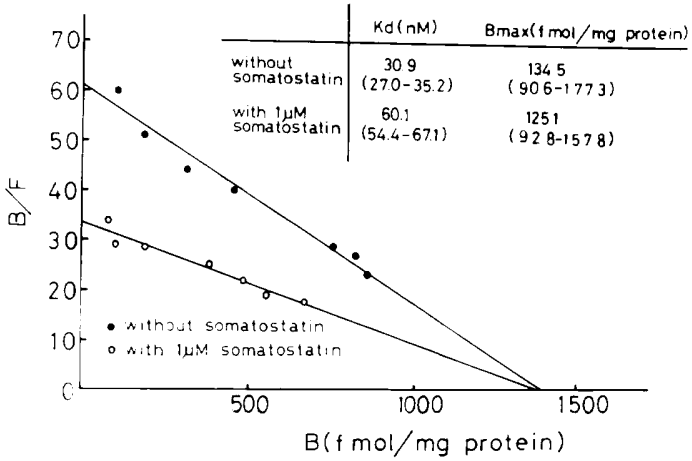

Fig. 5. Scatchard plots of saturation data of ${ }^{3} \mathrm{H}$ oxo-M binding buffered with $\mathrm{Na}-\mathrm{K}$ phosphate solution. A single binding site with a $K_{d}$ value of $30.9 \mathrm{nM}$ was obtained by switching the buffer to $\mathrm{Na}-\mathrm{K}$ phosphate solution (O). Somatostatin decreased affinity of ${ }^{3} \mathrm{H}$-OxO-M binding to the rat hippocampus in a pattern identical to that in Fig. 1 (O).

connection with neuronal loss of the nucleus basalis of Meynert is popularly advocated (8). These are the reasons why we directed our attentions toward the relationship between mAchR and somatostatin in the hippocampus which is associated with memory functions.

The idea that there are two or three subtypes of $m A c h R$ agonist binding sites, 


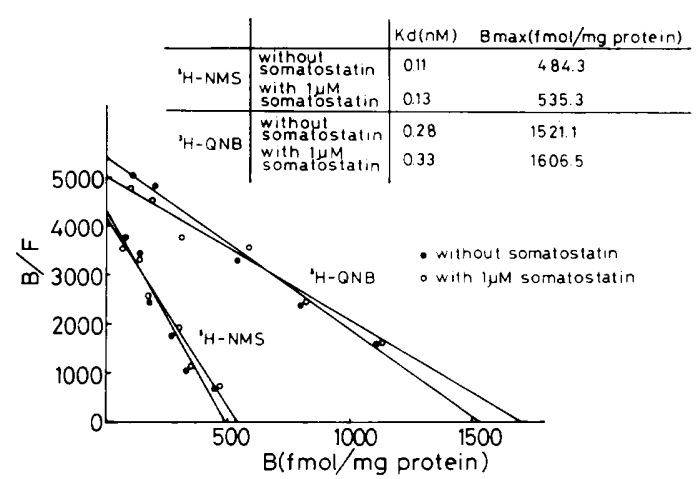

Fig. 6. Scatchard plots of saturation data of ${ }^{3} \mathrm{H}$ NMS and ${ }^{3} \mathrm{H}-\mathrm{QNB}$ binding with $(\mathrm{O})$ and without (O) somatostatin. $P_{2}$ fraction of the rat hippocampus was incubated with increasing concentrations of ${ }^{3} \mathrm{H}$ ligand at $30^{\circ} \mathrm{C}$. Somatostatin had no effect on ${ }^{3} \mathrm{H}$ antagonist binding.

while a useful antagonist binds to all types of $m A c h R$ in equal affinity, is accepted among not all, but many pharmacologists $(9,10)$. In our experiments, the presence of two components of agonist binding site was observed through saturation and inhibition experiments. Dissociation constants of agonist binding sites obtained from inhibition experiments are inconsistent with those from saturation experiments. It may be due to the difference between oxotremorine and oxotremorine- $\mathrm{M}$. The oxotremorine $/{ }^{3} \mathrm{H}-\mathrm{NMS}$ competition curve fitted a single site model by adding somatostatin. otherwise it fitted a two binding site model. In contrast, two binding sites were preserved after adding somatostatin in the case of the saturation experiments. The mechanism for these phenomena is difficult to explain. Nevertheless, it is assumed that somatostatin accelerates conformational changes of oxotremorine high affinity binding sites to the low affinity binding state, since the $K_{i}$ value with somatostatin is close to the $K_{L}$ value without somatostatin.

From our experiments, no influence of somatostatin on mAchR antagonist binding was confirmed. It has been reported that $M 1$ muscarinic receptors are dominant in the hippocampus ( $80 \%$ of the total receptors) (11) and the activation of these postsynaptic receptors modifies membrane phosphoinosi- tides $(12,13)$ and ion fluxes, resulting in cellular excitation. Cockcroft and Gomperts suggest that GTP binding protein may be involved in these membrane transduction mechanisms (14). On the other hand, the activation of these kind of receptors causes an increase of CGMP. It is advocated that arachidonic acid, prostaglandin and other metabolites are associated with this transduction in presence of $\mathrm{Ca}$ ion (15). Therefore, somatostatin may have some influence on interaction among these molecules which exist in the synaptic membrane and change the functional state of the receptor protein. Taking these facts into consideration, the mechanisms of the regulatory process of somatostatin on mAchR should be elucidated.

Acknowledgement: The authors express their sincere gratitude to Dr. H. Yoshida, Dr. S. Uchida and Mr. A. Mizushima of the Department of Pharmacology, Osaka University School of Medicine, for assistance in computer analysis. This study was supported in part by a Grant-in-aid for Science Research. No. 58370023, from the Ministry of Education, Science and Culture. Japan.

\section{References}

1 Wood, P.L., Cheney, D.L. and Costa, E.: Interaction of neuropeptides with cholinergic septalhippocampal pathway: indication for a possible trans-synaptic regulation. In Cholinergic Mechanisms, Edited by Perpru, G. and Ladinsky, H.. p. 715-722, Plenum Press, New York (1981)

2 De Robertis, E., Pellegrino De Iraldi, A., Rodoriguez De Lores Arnaiz, G. and Saloganicoff, L.: Cholinergic and non-cholinergic nerve endings in rat brain. I. Isolation and subcellular distribution of acetylcholine and acetyicholinesteráse. J. Neurochem. 9, 23-35 (1962)

3 Lundberg, J.M., Hedlund, B. and Bartfai, T.: Vasoactive intestinal polypeptide enhances muscarinic ligand binding in cat submandibular salivary gland. Nature 295, 147-149 (1982)

4 Tanaka, S. and Tsujimoto, A.: Somatostatin facilitates the serotonin release from rat cerebral cortex, hippocampus and hypothalamus slices. Brain Res. 208, 219-222 (1981)

5 Malthe-Sørenssen, D., Wood, P.L., Cheney, D.L. and Costa, E.: Modulation of the turnover rate of acetylcholine in rat brain by intraventricular injections of thyrotropin-releasing hormone, somatostatin, neurotensin and angiotensin II. J. Neurochem. 31, 685-691 (1978)

6 Peterfreund, R.A. and Vale, W.W.: Muscarinic 
cholinergic stimulation of somatostatin secretion from long term dispersed cell cultures of fetal rat hypothalamus: inhibition by gamma-aminobutyric acid and serotonin. Endocrinology 112 , 526-534 (1983)

7 Morrison. J.H., Rogers, J.B., Scherr, S., Benoit, R. and DeGirolami, U.: Neuropathology of the somatostatin system in neocortex of patients with senile dementia of the Alzheimer's type (SDAT). Abstract, Society for Neuroscience, 14th Annual Meeting 2, 894 (1984)

8 McGeer, P.L., McGeer, E.G., Suzuki, J. and Norman, M.: Cholinergic and noradrenergic systems in aging, Alzheimer's disease and Down's syndrome. Abstract, Society for Neuroscience, 14th Annual Meeting 2, 995 (1984)

9 Ehlert, F.J., Dumont, Y., Roeske, W.R. and Yamamura, H.I.: Muscarinic receptor binding in rat brain using the agonist, $\left[{ }^{3} \mathrm{H}\right]$ cis-methyldioxolane. Life Sci. 26, 961-967 (1980)

10 Birdsall, N.J.M., Hulme, E.C., Stockton, J., Burgen, A.S.V., Berrie, C.P., Hammer, R., Wong, E.H.F. and Zigmond, M.J.: Muscarinic receptor subclasses: Evidence from binding studies. In
CNS Receptors-From Molecular Pharmacology to Behavior, Edited by Mandel, P. and DeFeudis, F.V., p. 323-329, Raven Press, New York (1983)

11 Flynn, D.D. and Potter, L.T.: Different effects of $\mathrm{N}$-ethylmaleimide on $\mathrm{M} 1$ and $\mathrm{M} 2$ muscarinic receptors in rat brain. Proc. Natl. Acad. Sci. U.S.A. 82, 580-583 (1985)

12 Weiss, S.J., Mckinney, J.S. and Putney, J.W.: Receptor-mediated net breakdown of phosphatidylinositol 4,5-biphosphate in parotid acinar cells. Biochem. J. 206, 555-560 (1982)

13 Jones, L.M., Kirk, C.J. and Michell, R.H.: Molecular events following activation of muscarinic receptors: the role of inositol phospholipids. Scand. J. Gastroenterol. Supp. 17, 33-41 (1982)

14 Cockcroft, S. and Gomperts, D.: Role of guanine nucleotide binding protein in the activation of polyphosphoinositide phosphodiesterase. Nature 314, 534-536 (1985)

15 Berridge, M.J.: The role of membrane phospholipids in receptor transducing mechanisms. In Cell Surface Receptors. Edited by Strange, P.G., p. 207-226. Ellis Horwood, New York (1983) 